\title{
Impacts of Discharge of Desalination Plants on Marine Environment at the Southern Part of the Egyptian Red Sea Coast (Case Study)
}

\author{
Hussein Nasr, Mohsen Yousef ${ }^{*}$, Hashem Madkour \\ National Institute of Oceanography and Fisheries, Red Sea Branch, Hurghada, Egypt \\ Email address: \\ mohsen_102002@yahoo.com (M. Yousef) \\ *Corresponding author
}

\section{To cite this article:}

Hussein Nasr, Mohsen Yousef, Hashem Madkour. Impacts of Discharge of Desalination Plants on Marine Environment at the Southern Part of the Egyptian Red Sea Coast (Case Study). International Journal of Ecotoxicology and Ecobiology. Vol. 4, No. 3, 2019 , pp. 66-70. doi: $10.11648 /$ j.ijee.20190403.12

Received: August 19, 2019; Accepted: September 6, 2019; Published: September 24, 2019

\begin{abstract}
There are many researches illustrated that almost lots mankind is suffering from shortage fresh water supply, both of quality and quantity. Considering water inadequate concerns approximately 80 countries and has caused some dangerous results in many places. The water shortage phenomenon is becoming a serious worldwide problem that impacts people's daily life and obstacle the social development. Because of the population increasing and expansion of industrial and agricultural activities, the governments of many countries get one's way to implement the desalination plants. A desalination plants is an industrial system that would have the potential to have an effect on environmental ecosystem. This study monitored variety of environmental impacts can be caused by desalination plants. It's considers a case study for two of the desalination plants located at Shalateen city at Red sea governorate namely; Marsa Humira and Shalateen desalination plants. The investigation unconcealed that there are distinct impacts of the reject water on the marine ecosystem in the front of the two studied stations. The photographs that has been taken to the biota exist in the marine area around the stations elucidated some of coral reefs affected by the discharge of the saline reject around. Coral reef and sea grass are the most biota affected due to the salty discharges that exceed the safe limits for those to be in a healthy condition.
\end{abstract}

Keywords: Desalination Plants, Coral Reefs, Heavy Metals

\section{Introduction}

Freshwater accounts for only $2.5 \%$ of the total volume of water on earth $[1,2]$. Many regions are suffering from freshwater shortage due to raising water using up and climatic changes that are decrease the reliability of conventional water resources like groundwater sources [3]. For these reasons, water agencies have begun to make to reduce demand for water and to raise water supply by encouraging a new technical method like seawater desalination [4]. The desalination technology is one of recent inventions to produce freshwater from a salt-water solution [5].

Previous studied have reported the potential environmental effects from the discharges of the desalination plants in marine environments $[6,8]$. The desalination plants discharge their reject into the marine environment, and this resulted in impact to marine life [9]. Seawater salinity might not be different in profile from the surface to the bottom while in the ambient area of the discharge reject water it can fluctuate between the surface and to ten meters depth [10].

There is a remarkable relationship between change in the environmental salinity and the impacts on marine life [11]. In the long-term, salinity stress might be impact on the growth and reproduction of coral reef and this leads to mortality [12]. Mobile species such as plankton and fish are the first most likely sort of marine life to be influenced due to changes in the seawater temperature [13].

The present study aimed to illuminate the impacts of the Marsa Humira and Shalateen desalination plants on the marine environment around particularly on coral reef ecosystem. 


\section{Materials and Methods}

\subsection{Area of the Study}

The two desalination plants studied in the present study have a special geographical characteristic. The study was carried out at Marsa Humira and Shalateen desalination plants figure 1. The latitude and longitude coordinates of the studied stations were recorded using the survey vessel's Garmin, Global Positioning System (GPS) unit navigation system.

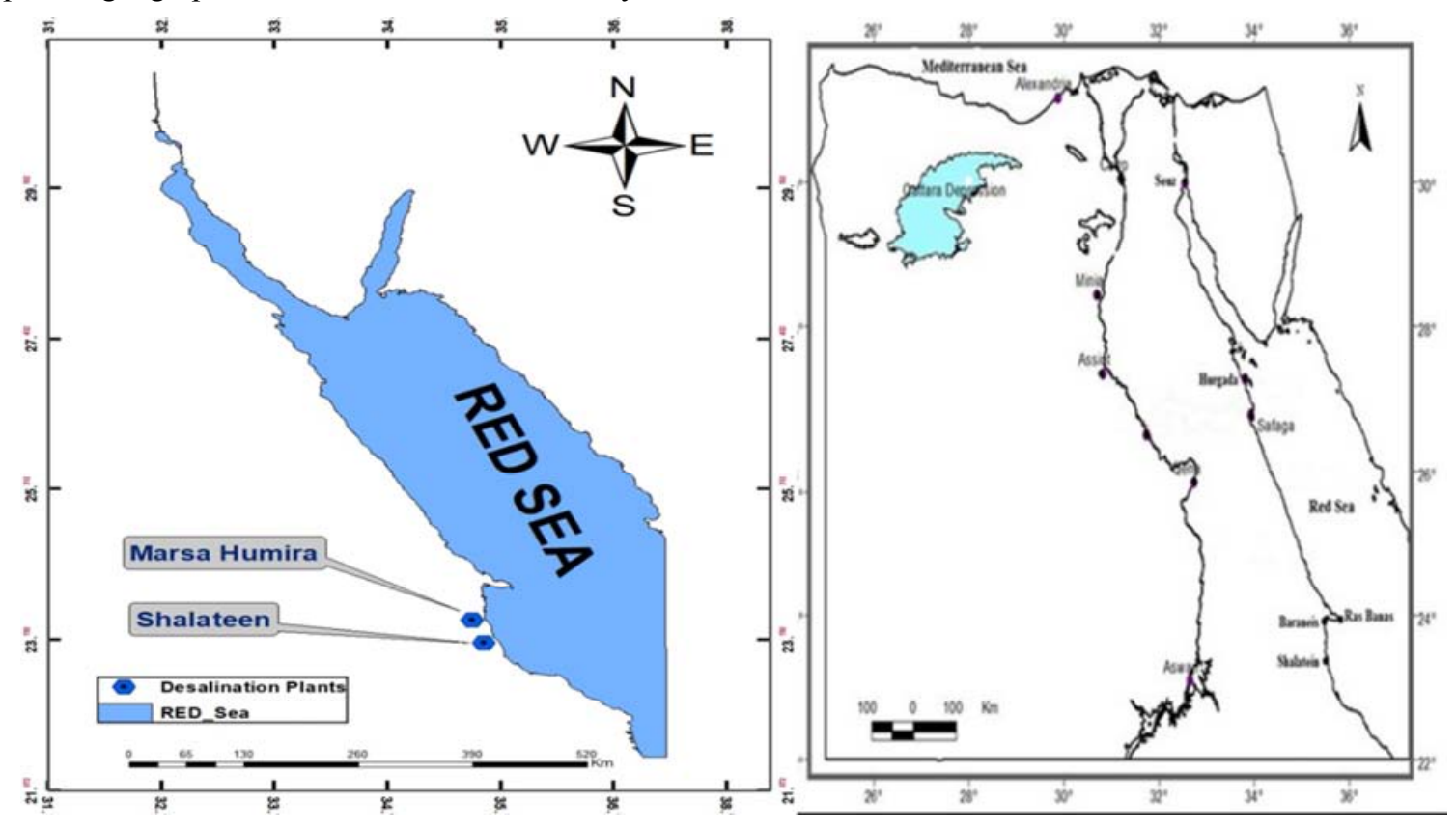

Figure 1. Shows map of Studied areas along the Red Sea coast, Egypt.

\subsection{Field Studies}

The environmental factors were measured in the feed (sea water) and reject water (the discharge of the desalination plants). These factors include; temperature of water, $\mathrm{pH}$, Total dissolved solids (TDS), Salinity (Sal), Dissolved Oxygen (DO), Turbidity (Turb.) and Oxidation Reduction Potential (ORP). Factors were measured using YSI Pro DSS Multi-Parameter Water Quality Meter. Scopa Diving/ or snorkeling to survey the marine area around the stations studied were used. Photography used to take photos for the marine area include the coral reefs and other aquatic animals present. This was done using digital underwater camera. line transect was used to follow the conditions of the coral reefs in the whole area studied.

\subsection{Laboratory Measurements}

\subsubsection{Determination of Nutrients}

Water samples were taken to measure the nutrients includes; ammonium $\left(\mathrm{NH}_{4}\right)$, nitrite $\left(\mathrm{NO}_{2}\right)$, nitrate $\left(\mathrm{NO}_{3}\right)$, phosphate $\left(\mathrm{PO}_{4}\right)$ and silicate $\left(\mathrm{SiO}_{2}\right)$ using GenWay Spectrophotometer analysis apparatus.

\subsubsection{Determination of Heavy Metals}

Nine of heavy metals were determined in both feed and reject waters at the two studied stations. The determined heavy metals include; Iron (Fe), Manganese (Mn), Zinc ( $\mathrm{Zn}$ ), Copper $(\mathrm{Cu})$, Lead $(\mathrm{Pb})$, Nickel $(\mathrm{Ni})$, Cobalt $(\mathrm{Co})$ and Cadmium (Cd). Determination of heavy metals has been done using the Atomic Absorption Spectroscopy (AAS) with flame methods. All physical and chemical analysis has been done according to according [14].

\section{Results and Discussion}

\subsection{Discerption of the Sites}

Site 1: Marsa Humera station

This site located onshore of Marsa Humera area, at the southern part of Egyptian Red Sea $30 \mathrm{~km}$ north Shalateen city figure 1. It impacted by desalination plant which discharge about $300 \mathrm{~m}^{3} /$ per day of saline water. This site was characterized by low diversity of coral and marine organisms. Sea water around that area may be featured by down swells and waves and characterized by sandy seabed.

Site 2: Shalateen station

This site located offshore of Shalateen area, at the southern part of Egyptian Red Sea, Al Shalateen city, which extends from $15 \mathrm{~km}$ north on the Branis road figure 1 . There are two desalination plant units in the Shaltin station. The feeding of both units is from seawater. This is by four pipelines extending across the tidal range for about 580 meters to a depth of about 8 meters. Both units discharge about 10000 $\mathrm{m}^{3} /$ per day of reject water in marine environment around.

\subsection{Physicochemical Impact of Reject Water}

Table 1 revealed that there is distinct increase in all measured physicochemical parameters concentrations of the reject water of both desalination plants studied compared to 
the feed source. RPS stated that the desalination process may increase the temperature of the reject water above the ambient seawater (feed water) [15]. Dawoud et al reported that the desalination processes produce large quantities of brine water, which may be increased in temperature [16]. Tularam and llahee reported that the reverse osmosis produces reject water with salinity up to twice that of seawater [7]. RPS reported that the de-chlorination process can reduce the $\mathrm{pH}$ of the reject water than the seawater [15]. This opposite to the results of $\mathrm{pH}$ in the Shalteen desalination plant and this may be due to the shortage in the dechlorination process. The present study revealed that there is a reduction in dissolved oxygen values in reject water. Water Consultants International Lattemann and Hopner reported that a shortage in dissolved oxygen can impact marine life [ 6 and8]. Lattemann and Hopner stated that the addition of oxygen consuming chemicals can reduce dissolved oxygen in RO plants [8]. The parameters measured in the feed and reject water of the two studied desalination plants were tested for the one-way ANOVA test. The test revealed that there is a significant difference $(p<0.05)$ between all measured physicochemical parameters of the feed and reject water except for TDS and ORP.

Table 1. Show the mean and standard deviation of the physicochemical parameters measured in the feed and reject waters of Marsa Humira and Shalateen desalination plants.

\begin{tabular}{llll}
\hline Location & Marsa Humira & Shalateen \\
\hline Factors & Feed & Reject & Feed \\
\hline Temp & $31.403 \pm 0.006$ & $31.633 \pm 0.058$ & $33.067 \pm 0.462$ \\
pH & $7.910 \pm 0.010$ & $7.081 \pm 0.001$ & $7.823 \pm 0.040$ \\
TDS & $40.463 \pm 0.006$ & $41.007 \pm 0.012$ & $42.547 \pm 0.739$ \\
Sal & $42.353 \pm 0.006$ & $55.697 \pm 0.006$ & $43.210 \pm 0.139$ \\
DO & $4.100 \pm 0.000$ & $2.700 \pm 0.100$ & $4.967 \pm 0.808$ \\
Turb. & $2.733 \pm 0.544$ & $3.400 \pm 0.082$ & $2.433 \pm 0.047$ \\
ORP & $245.267 \pm 0.252$ & $232.000 \pm 1.732$ & $225.900 \pm 13.139$ \\
\hline
\end{tabular}

\subsection{Heavy Metals Nutrients Impact}

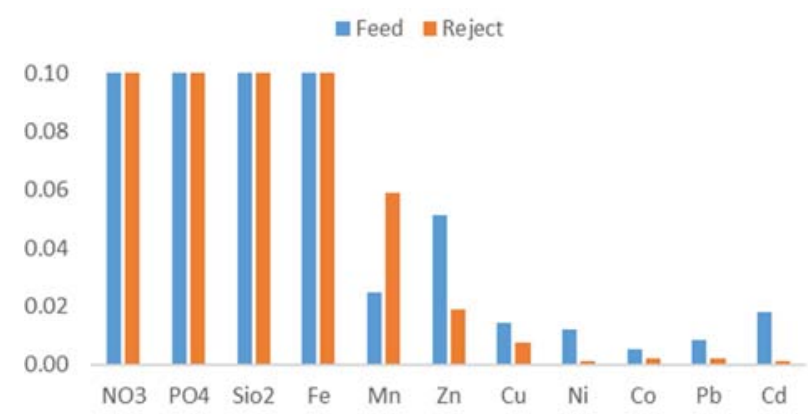

Marsa Humira Desalination Plant

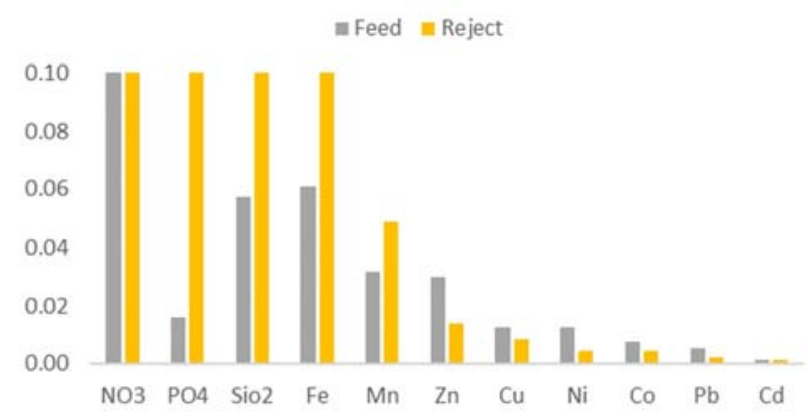

\section{Shalateen Desalination Plant}

Figure 2. Show the mean heavy metals and nutrients measured in the feed and reject water of Marsa Humira and Shalateen Desalination Plants.

The statistical analysis revealed that there is highly significant difference $(\mathrm{p}<0.05)$ between feed and reject water for all measured heavy metals. In contrast, there is a non-significant difference $(p>0.05)$ between feed and reject water for all measured nutrients measured. Figure 2 illustrate that there are differences between the feed and reject waters in the concentrations of the measured heavy metals and nutrients. Lattemann and Hopner stated that the reversed osmosis and desalination plants produce reject water with heavy metals in relatively low concentrations [8]. Hashim and Hajjaj stated that any heavy metals that naturally occur in sea water are leached through corrosion or added in the pretreatment process will be concentrated during the RO process after the freshwater is removed [17]. Raventos and GarciaRubies reported that the addition of nitrogen and iron during the RO process has potential to affect primary productivity as they are potentially limiting elements in marine system [18]. Roth and Muller-Parker et al reported that corals have a mutualistic relationship with dinoflagellates; genus (Symbiodinium) which fused to the coral reef's tissue where they give organic matter to the coral via photosynthesis in return of nutrients $[19,20]$.

\subsection{Impact on Marine Ecosystem (Coral Reef Ecosystem)}

The present investigation focused mainly on the impact of reject water discharged from two desalination plants on the marine ecosystem especially on coral reefs figures $3 \& 4$. The study revealed that there are highly distributed coral reefs, macro algae, sea grass, shellfish, sea urchins at the tidal zone around the discharge of Marsa Humira desalination plant. Birkeland reported that coral reefs considered one of the richest habitats in the marine environments, providing great biodiversity, biomass and productivity [21]. The percentage of coral reef cover around the effluent of the studied desalination plants was computed. The percent cover of alive hard coral reef around the discharge of the desalination plant was $30 \%$ while for alive soft coral was 
represented by $5 \%$. The percent cover of dead coral affected by saline rejected water was $65 \%$ while for alive massive corals (ports sp, favia sp, fungi sp, and platigra $\mathrm{sp}$ ) was $70 \%$. The percent cover of branching corals of type (Acropora sp, pocillopora $\mathrm{sp}$, Millipora $\mathrm{sp}$ ) was $30 \%$.

The present investigation recorded increases in salinity values of Marsa Humira and Shalateen station's reject water (55.697 $\pm 0.006 \mathrm{ppt})$ and $(54.72 \pm 0.49 \mathrm{ppt})$ respectively. Coles reported that a lot of coral species are known to withstand salinities above (50 ppt) in locations such as the Arabian Gulf, Red Sea [22]. The present study recommended that rejected water should be diluted before discharge to the marine environment. salinity play a significant role in the growth of marine species disturbance to keep the coral reef healthy. Birkeland and Graham et al. stated that coral reefs are essential for local economies, fisheries and tourisms [21and 23].
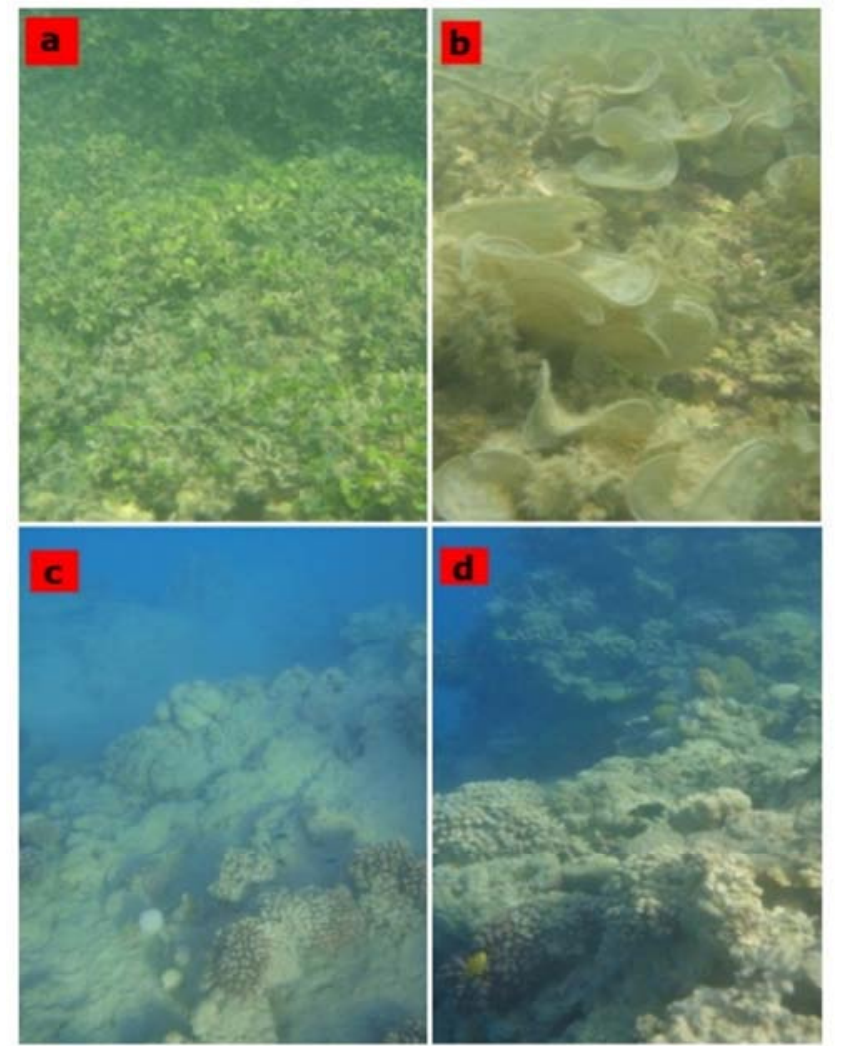

Figure 3. Shows the coral reefs impacted around the discharge of rejected water from Marsa Humira Desalination plant; (aandb) Shows growing green and prawn algae (Ulva intestinalis and Padina boryana) at tidal flat, (candd) explained the percent cover of alive hard coral reef $30 \%$ and the percent cover of life soft coral 5\%, the percent cover of dead coral $65 \%$, of saline water.

Jones reported that the tolerance limits of marine organisms to variation in salinity degrees is an essential in determine marine disturbance and population [24]. Increase the salinity can be of benefit for some of these organisms such as shellfish and also can have an adverse impact on other species. In the present study there is another problem associated to Shalateen station is it very close to the beach area and this may cause severe impact. So, the present study recommended that it is necessary to extend the drain pipes into the tide area far from the beach. Einav and Lokiec reported that the vulnerability of marine ecosystem is likely to be influenced by the ecosystem's resilience to change [25]. Lattemann and Hopner reported that many marine ecosystems and species can tolerate or recover from short term changes in temperature, salinity and chemicals beyond normal levels, however, permanent changes are likely to result in mobile species relocating [8]. Lattemann and Hopner stated that the biota, like seagrass, coral and macroalgae are affected directly and it will be decline in health or die [8].
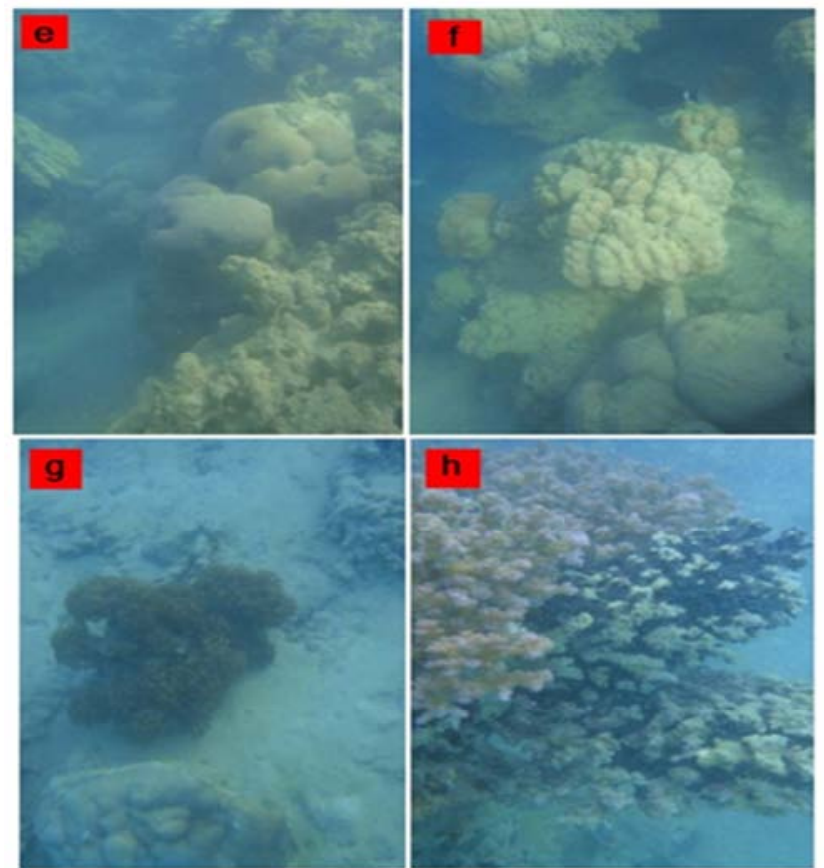

Figure 4. Shows the Shalateen Desalination Plants (eandf) explained the percent cover of alive hard corals (massive corals about 70\%), of types (ports sp, favia sp, fungi sp, and platigra sp), while the percent cover of branching corals about 30\%), of types (Acropora sp, Pocillopora sp, Millipora sp) (g) showed the percent cover of soft coral reached 5\% . (h) shows the bleaching of coral impacted.

\section{Conclusion and Recommendation}

The present study concluded that in spite of the needed to freshwater produced by desalination plants it cannot be neglected its impact on flora and fauna species around. Discharge of desalination plants to the marine environment with high salinity and total dissolved salts (TDS), causing complete destruction of most marine organisms, especially coral reefs. The strong evidence of this in the case study in our hands as a result of the exchange of desalination plants in the study sites of the growth of a dense type of green algae in front of the areas that are disbursed see the desalination plants. So, the study recommended that when the governorates attend to establish desalination plants it should be taken in account the environmental concepts. 


\section{Acknowledgements}

We would further like to acknowledge all members of environmental monitoring and the Pollution laboratory at Red Sea Branch for their extensive help and support in completing this work.

\section{Funding}

This work was supported by the National Institute of Oceanography and Fisheries, Red sea Branch.

\section{References}

[1] Oki, T., Kanae, S., (2006). Global hydrological cycles and world water resources. Science 313, 1068-1072.

[2] World Water Assessment Programme. (2009). The United Nations World Water Development Report 3: Water in a Changing World. UNESCO Paris.

[3] Bourne, G., (2008). California Desalination Planning Handbook. Sacramento: Center for Collaborative Policy, California State University Sacramento.

[4] Martin, C. A. (2015). Landscape water use in Phoenix, Arizona. Desert Plants.

[5] Einav, R., Harussi, K., Perry, D., (2002). The footprint of the desalination processes on the environment. Desalination 153, $41 e 154$.

[6] Water Consultants International, (2006). Environmental Literature Review and Position Paper for Perth Desalination Plant Two and Sydney Sea Water Reverse Osmosis Plant. Water Corporation of Western Australia.

[7] Tularam, G. A. and llahee, M. (2007). Environmental concerns of desalinating sea water using reverse osmosis. journal of Environmental Monitoring, 9, 805-813.

[8] Lattemann, S. and Hopner, T. (2008). Environmental impact of impact assessment of sea water desalination. Desalination, $220,1-15$.

[9] Frihy, O. E., Hassan, A. N., El Sayed, W. R., Iskander, M. M., and Sherif, M. Y. (2006). A review of methods for constructing coastal recreational facilities in Egypt (Red Sea) Ecological Engineering,27 (1), 1-12. doi: 10.1016/j.ecoleng.2005.11.001.

[10] Abdul-Wahab. S. (2007). Characterization of water discharge from two thermal power/ desalination plants in Oman. Environmental Engineering Science 24 3, pp 321-337.

[11] Gunter. G. (1961). Salinity and size in marine fishes. Copeia 1961, 2, pp 234-235.
[12] Coles SL, Jokiel PL (1978). Synergistic effects of temperature, salinity and light on the hermatypic coral Montipora verrucosa. Mar Biol 49: 187-195.

[13] Hiscock, K., Southward, A. J., Tittley, I. and Hawkins, S. J. (2004). Effect of changing temperature on benthic marine life in Britain and Ireland. Aquatic Conservation 14, 333-362.

[14] APHA. (2005). Standard Methods for the Examination of Water and Wastewater. 20th Ed. American Public Health Association Washington, D. C.

[15] RPS. (2008). Gorgon Project: Sea Water Uptake and Reverse Osmosis Brine Effluent Discharge Study: Environmental Quality Management Framework. Prepared for Chevron Australia Pty Ltd. Report No. M0751 I.

[16] Dawoud, Mohamed A. Al Mulla, Mohamed M. (2012). Environmental Impacts of Seawater Desalination: Arabian Gulf Case Study. International Journal of Environment and Sustainability ISSN 1927 -9566| Vol. 1 No. 3, pp. 22 - 37 (2012).

[17] Hashim, A. and Hajjaj, M. (2005). Impact of desalination plants fluid effluents on the integrity of sea water, with the Arabian Gulf in perspective. Desalination, 182, 373-393.

[18] Raventos, N., Macpherson, E. and Garcia-Rubies, A. (2006). Effect of brine discharge from a desalination plant on macrobenthic communities in the NW Mediterranean. Marine Environmental Research, 62, 1-14.

[19] Roth M. S. (2014). The engine of the reef: Photobiology of the coral - algal symbiosis. Frontiers in Microbiology, 5, 422 10.3389/fmicb.2014.00422.

[20] Muller-Parker G, D'Elia CF, Cook CB. (2015). Interactions Between Corals and Their Symbiotic Algae. In: Birkeland C, editor. Coral reef in the Anthropocene. Springer, P. 1-271.

[21] Birkeland, C., (2015). Coral Reefs in the Anthropocene, Coral Reefs in the Anthropocene. Springer, Dordrecht. https://doi.org/10.1007/978-94-017-7249-5.

[22] Coles, S. L. (1992). Experimental comparison of salinity tolerances of reef corals from the Arabian Gulf and Hawaii: Evidence for hyperhaline adaptation. Proc 7th Int. Coral Reef Symp, Guam. I, 227-234.

[23] Graham, N. A. J.; Wilson, S. K.; Jennings, S.; Polunin, N. V. C.; Bijoux, J. P.; Robinson, J. (2006). Dynamic fragility of oceanic coral reef ecosystems. Proc. Natl. Acad. Sci., 103 (22), 8425-8429.

[24] Jones, Ian. S. F. (2007). Desalination Plants: Potential impacts of brine discharge on marine life. The Ocean Technology Group.

[25] Einav, R. and Lokiec, F. (2003). Environmental aspects of a desalination plant in Ashkelon. Desalinat ion, 156, 79-85. 